https://www.journal-imab-bg.org

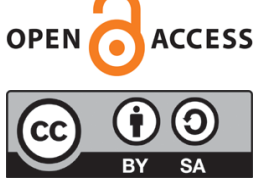

Original article

\title{
SEROLOGICAL CMV SCREENING IN WOMEN OF REPRODUCTIVE AGE AND IN PREGNANT WOMEN
}

\author{
Zhivka Stoykova 1,2 \\ 1) Laboratory of Virology, University Hospital St. Marina - Varna, Bulgaria \\ 2) Department of Microbiology and Virology, Medical University of Varna, \\ Bulgaria.
}

\begin{abstract}
:
Prenatal cytomegalovirus (CMV) screening is not routinely conducted in Bulgaria. According to our previous data, CMV infection is widespread in our region with a total seroprevalence of $78.4 \%$. Such high seroprevalence may have profound effect over the incidence of congenital CMV (cCMV) infections. We aimed in determination of the serological CMV status of both women in reproductive age and pregnant women.

Materials and methods: $(15-49$ y)

Retrospective: 1612 women in childbearing age

Prospective: 121 pregnant women (14-41 y)

ELISA tests for detection of anti-CMV $\operatorname{IgM} / \operatorname{IgG}$ and for avidity determination of anti-CMV IgG, EUROIMMUN, Germany.

Results: From a total of 1612 women in childbearing age, 1362 (84.5\%, 95\% CI: 82.73 - 86.27) were antiCMV IgG positive.

From a total of 121 pregnant women, 105 (86.8\%, 95\% CI: 80.77 - 92.83) were anti CMV IgG positive and 12 (9.9\%, 95\% CI: 4.58 - 15.22\%) were anti CMV IgM positive. We got a high IgG avidity index in all seropositive pregnant women, including those with $\operatorname{IgM}$ positive results.

Conclusions: CMV infection is highly prevalent in women in reproductive age in Bulgaria and the estimated hypothetical population transmission risk in our region is a total of $7 \%$.

We compared the preliminary retrospective data with the data obtained from a real situation of 121 pregnancies and got very similar results. Since almost $10 \%$ of the pregnant women had evidence of acute or recent infection, this required us to perform the anti-CMV IgG avidity test. We got a high IgG avidity index in all pregnant women.
\end{abstract}

Keywords: CMV, serological screening, reproductive age, pregnancy, ELISA

\section{INTRODUCTION:}

Human cytomegalovirus is ubiquitous herpesvirus that establishes lifelong latency after the primary infec- tion. Latent infection may become reactivated and productive after stimuli such as inflammation or immune impairment due to pregnancy, treatment with immunomodulating agents such as corticosteroids, chemotherapy and post-transplantation immunosuppressive therapy [1].

CMV is well known as an important pathogen contributing to morbidity and mortality in immunocompromised hosts and posttransplant recipients, but CMV is also a leading cause of congenital infections across the world. It is a major health problem, because it is the commonest nonhereditary cause of hearing loss and a significant cause of neurodevelopmental delay [2]. According to meta-analysis data transmission to the fetus occurs in $14.2-52.4 \%$ (average of $32.4 \%$ ) of primary infections of the mother, whereas $1.1-1.7 \%$ (average of $1.4 \%$ ) of nonprimary infections lead to fetal infection [3]. In that aspect it is important to determine the stage of the infection in pregnant women, which is directly related to the risk of transmission of the virus to the fetus.

The overall birth prevalence of congenital CMV infection is reported to occur in average $0.64 \%$ of pregnancies, but varies considerably among different study populations from $0.3 \%$ to $2.3 \%$ of all live births [4]. Limited studies in developing countries, including Latin America, Africa and Asia have reported a much higher birth prevalence of cCMV infection ranging from 0.6 to $6.1 \%$ of all pregnancies [5].

Prenatal serological screening is not routinely conducted in any country, but it may permit early identification of at-risk pregnancies or infected fetuses and has attracted increasing interest in recent years [6].

According to our previous data, CMV infection is widespread in Bulgaria with a total seroprevalence in the population of $78.4 \%$ [7]. Such high seroprevalence in the region may have profound effect over the incidence of cCMV infections in the region.

AIM:

To estimate the CMV serological status both in women in childbearing age and pregnant women in Northeastern Bulgaria and to determine the stage of CMV infection in pregnant women. 


\section{MATERIALS AND METHODS:}

Study population:

- Retrospective: 1612 women in childbearing age (15-49 years old, according to WHO definition), average 30.55 y. ( $\mathrm{SD} \pm 9.75)$, hospitalized for various reasons at the University Hospital of Varna for the period 20032015.

- Prospective: 121 clinically healthy pregnant women (14-41 years old), average 28.66 y. ( $\mathrm{SD} \pm 5.88$ ), serum samples were collected in 2018. Out of them $62 \%$ were in the first, $14.1 \%$ - in second and $23.9 \%$ - in the third trimester of pregnancy.

\section{METHODS:}

- Commercial ELISA test kits for detection of specific anti-CMV IgM/IgG and for determination of avidity of specific anti-CMV IgG, EUROIMMUN, Germany were performed, according to the manufactures' recommendations.

\section{RESULTS:}

From a total of 1612 women in childbearing age, $1362(84.5 \%, 95 \%$ CI: 82.73 - 86.27) were anti-CMV IgG positive and $250(15.5 \%, 95 \%$ CI: 13.73 - 17.27) were anti CMV IgG negative.

From a total of 121 pregnant women, 105 (86.8\%, 95\% CI: 80.77 - 92.83) were anti-CMV IgG positive and $16(13.2 \%, 95 \%$ CI: 7.17 - 19.23) were anti CMV IgG negative.

From a total of 121 pregnant women $12(9.9 \%, 95 \%$ CI: 4.58 - 15.22\%) were anti-CMV IgM positive.

We got a high IgG avidity index in all seroposi- tive pregnant women, including those with an anti-CMV IgM positive result.

\section{DISCUSSION:}

The incidence of congenital cytomegalovirus infections in a given population depends on a large scale to the maternal CMV status. The vertical transmission risk has long ago been estimated in the literature as approximately $40 \%$ in case of primary maternal infection [8] and $1 \%$ in case of reactivation of the infection in previously immune mother [9]. In order to investigate the problem in our region, preliminary we first went to study the serological status of a large number of women of reproductive age. Of the 1612 women in childbearing age tested $1362(84.5 \%)$ were anti-CMV IgG positive, with a mean age of 31.29 years $(\mathrm{SD} \pm 10$ ). The remaining 250 women of childbearing age [15.5\%] were non-immune and their mean age was 26.48 years ( $\mathrm{SD} \pm 9.16)$, which is almost 5 years younger than the age of the infected one. The risk ratio (infected women versus non-immune) is 5.5 and after accounting for sampling variability, the young age could be considered a risk factor of acquiring primary CMV infection. Based on the literature data and taking in consideration our results from the serological screening of women in childbearing age we were able to estimate the hypothetical population risk for vertical transmission in our region as a total of maximum $7 \%$ (tabl. 1). To support this hypothetical data with a real situation in our previous study of 187 symptomatic newborns under 1 month we found $6.4 \%$ of them anti-CMV IgM positive or the data strongly suggests cCMV infection in this infants [10].

Tabl. 1. Hypothetical population risk for vertical transmission in women in childbearing age in the study population $(n=1612)$.

\begin{tabular}{|c|c|c|}
\hline $\mathrm{N}=1612$ & $\begin{array}{c}\text { Vertical transmission risk } \\
(\text { references } *(8) * *(9))\end{array}$ & $\begin{array}{c}\text { Hypothetical population risk } \\
\text { in our study }\end{array}$ \\
\hline $\begin{array}{c}\text { Non-immune women } \\
(\mathrm{n}=250) 15.5 \%\end{array}$ & $40 \% *$ & $6.2 \%$ \\
\hline $\begin{array}{c}\text { Infected women } \\
(\mathrm{n}=1362) 84.5 \%\end{array}$ & $1 \% * *$ & $0.8 \%$ \\
\hline
\end{tabular}

We compared the preliminary retrospective data we got with the data obtained from a real situation of 121 pregnancies and we got very similar results. 105 (86.8\%) of the 121 pregnant women in our study were anti CMV IgG positive and $16(13.2 \%)$ were anti-CMV IgG negative. The last group of non-immune women was in high risk to transmit the virus in case of eventual primary maternal infection. The apparent paradox of maternal seropositivity as a risk factor for congenital CMV infection can be explained as follows: previously seronegative pregnant women are at much higher risk (40\%) of transmitting CMV to their fetuses compared with seropositive preg- 
nant women (1\%). However, the risk of actually acquiring an infection during a pregnancy should be taken into consideration. This risk seems relatively low for seronegative women and relatively high for seropositive women. This is supported by previous studies which data indicate the risk to be higher in highly seropositive populations probably due to cultural and behavioral differences [11, 12].

Reactivation of endogenous CMV or reinfection with a different strain could lead to intrauterine transmission. Yamamoto et al. tested sera from 40 mothers of congenitally infected infants for strain-specific anti-CMV antibodies and confermed that maternal reinfection by new strains of cytomegalovirus is a major source of congenital infection in this population [13]. However reinfection is usually asymptomatic and defing seropositive pregnant women at risk of transmission is presently not possible with serology markers. Maternal primary infection can be confirmed reliably by the seroconversion (CMV IgG negative to CMV IgG positive) when a baseline serum sample from either the earliest antenatal visit or prior to conception is available. When such an early serum sample for comparison is not available, the detection of both CMV $\mathrm{IgG}$ and $\mathrm{IgM}$ antibodies may indicate a recent primary infection [14]. Seroconversion, representing a primary infection, occurs annually in approximately $1-2 \%$ of seronegative pregnant women [15]. Reactive CMV IgM may be found in both primary and non-primary infections and in many cases may persist for months following primary infection. It does not reliably predict the risk for congenital infection [16]. An algorithm for dealing in such cases is reviewed by Manicklal et al.: A reactive CMV $\operatorname{IgM}$ should be further evaluated by determining the maturity of the CMV IgG antibodies with avidity test. Low-affinity CMV IgG antibodies (those that bind less tightly with their target protein) are produced in the first 18 to 20 weeks after infection. A subsequent maturation process generates IgG antibodies with higher avidities. A high CMV IgG avidity index therefore excludes a recent primary infection and when detected before 12 to 16 weeks of gestation indicates a significantly lower risk of congenital infection. On the contrary, low-avidity IgG antibodies together with a reactive CMV IgM strongly supports a maternal primary infection in the preceding 3 or 4 months [14]. Numerous fetal structural and growth abnormalities have been described and associated with cCMV infection. Ultrasound is not invasive, but an in- sensitive method for detecting cCMV, missing up to $50 \%$ of the infected fetuses [17]. As described previously there is $40 \%$ risk of vertical transmission following primary maternal infection. This substantial risk justifies invasive prenatal testing of amniotic fluid (AF) in such cases. CMV PCR from AF is the reliable assay for confirming congenital infection. Because the interval between maternal and detectable fetal infection is at least 6 to 8 weeks, amniocentesis should be performed at 20 to 21 weeks of gestation and at least 7 weeks following maternal infection in order to escape false negative results $[18,19]$.

Testing for anti-CMV IgM, as an indicator of acute or recent infection is the most widely used worldwide method for screening pregnant women, but the significance of the results is limited by the possible persistence of specific IgM over time, the fact that they are also produced during episodes of reactivation or reinfection, and possible cross-reactions with other viruses [20]. Since 12/ 121 (nearly 10\%) of the pregnant women we tested had serological evidence of acute or recent infection (antiCMV IgM positive), this required us to perform the antiCMV IgG avidity test. We got a high IgG avidity index $(>60 \%)$ in all seropositive pregnant women, which make the test very reliable for determination of the phase of the infection and defining the risk of transmission of the virus to the fetus. A drawback of our study is the fact that almost $24 \%$ of pregnant women were in the third trimester of pregnancy at the time of the sample collection. High avidity index in them does not exclude primary infection or reinfection with new strain in very early pregnancy or around the conception.

\section{CONCLUSIONS:}

We found high CMV seroprevalence in both groups women of childbearing age and in pregnant women, which may have profound effect over the incidence of congenital CMV infections in our region. We estimated the hypothetical population risk for CMV transmission as 7\%, based on the preliminary large scale serological screening of women in childbearing age. Our data indicate high seroprevalence of $86.8 \%$ in the group of pregnant women and respectively $13.2 \%$ of them were non-infected. In the absence of proven therapeutic options, two different strategies should be applied in both groups in order to reduce the rate of cCMV infection - active monitoring and prevention of primary infection. 


\section{REFERENCES}

1. Mocarski E, Shenk T, Pass R. Cytomegaloviruses. In: Fields virology. 5th ed. Fields BN, David M Knipe DM, Peter M Howley PM. (eds) Philadelphia: Wolters Kluwer Health/Lippincott Williams \& Wilkins, 2007. pp.27012772.

2. Demmler-Harrison GJ. Congenital cytomegalovirus: Public health action towards awareness, prevention, and treatment. J Clin Virol. 2009 Dec; 46 Suppl 4:S1-5. [PubMed] [Crossref].

3. Kenneson A, Cannon MJ. Review and meta-analysis of the epidemiology of congenital cytomegalovirus (CMV) infection. Rev Med Virol. 2007 JulAug;17(4):253-76. [PubMed] [Crossref].

4. Boppana SB, Ross SA, Fowler KB. Congenital cytomegalovirus infection: clinical outcome. Clin Infect Dis. 2013 Dec;57 Suppl 4:S178-81. [PubMed] [Crossref].

5. Lanzieri TM, Dollard SC, Bialek SR, Grosse SD. Systematic review of the birth prevalence of congenital cytomegalovirus infection in developing countries. Int J Infect Dis. 2014 May; 22:448. [PubMed] [Crossref].

6. Nigro G, Adler SP. Cytomegalovirus infections during pregnancy. Curr Opin Obstet Gynecol. 2011 Apr; 23(2):123-8. [PubMed] [Crossref].

7. Stoykova Zh, Ivanova L, Todorova T, Kostadinova Ts, TsanevaDamyanova D. Seroprevalence of Cytomegalovirus in the North-Eastern Bulgarian Population, 2003-2015. Acta Microbiol Bul. 2016; 32(3):27-32.

8. Stagno S, Britt W. Cytomegalovirus infections. In: Infectious diseases of the fetus and newborn infant. 6th edn. Edited by Remington JS, O Klein
J, Wilson CB, Baker CJ. Philadelphia: Elsevier Saunders. 2006; p. 739.

9. Stagno S, Pass RF, Dworsky ME, Henderson RE, Moore EG, Walton PD, et al. Congenital cytomegalovirus infection: the relative importance of primary and recurrent maternal infection. $N$ Engl J Med. 1982 Apr 22;306(16): 945-9. [PubMed] [Crossref].

10. Stoykova $\mathrm{Zh}$, Ivanova LI, Todorova TT. The Role of Cytomegalovirus in Congenital and Early Postnatal Infections in Northeastern Bulgaria. Folia Med (Plovdiv). 2017 Sep 1; 59(3):298-302. [PubMed] [Crossref]

11. Colugnati FA, Staras SA, Dollard SC, Cannon MJ. Incidence of cytomegalovirus infection among the general population and pregnant women in the United States. BMC Infect Dis. $2007 \mathrm{Jul}$ 2;7:71. [PubMed] [Crossref].

12. Griffiths PD, McLean A, Emery VC. Encouraging prospects for immunization against primary cytomegalovirus infection. Vaccine. 2001 Jan 8;19 (11-12):1356-62. [PubMed] [Crossref].

13. Yamamoto AY, Mussi-Pinhata MM, Boppana SB, Novak Z, Wagatsuma VM, Oliveira Pde F, et al. Human cytomegalovirus reinfection is associated with intrauterine transmission in a highly cytomegalovirus-immune maternal population. Am J Obstet Gynecol. 2010 Mar;202(3):297.e1-8. [PubMed] [Crossref].

14. Manicklal S, Emery VC, Lazzarotto T, Boppana SB, Gupta RK. The "silent" global burden of congenital cytomegalovirus. Clin Microbiol Rev. 2013 Jan;26(1):86-102. [PubMed] [Crossref]

15. Hyde TB, Schmid DS, Cannon
MJ. Cytomegalovirus seroconversion rates and risk factors: implications for congenital CMV. Rev Med Virol. 2010 Sep;20(5):311-26. [PubMed] [Crossref].

16. Stagno S, Tinker MK, Elrod CFD, Cloud G, O'Beirne AJ. Immunoglobulin $\mathrm{M}$ antibodies detected by enzyme-linked immunosorbent assay and radioimmunoassay in the diagnosis of cytomegalovirus infection in pregnant women and newborn infants. J Clin Microb. 1985 Jun;21(6):930-5. [PubMed]

17. Picone $\mathrm{O}$, Teissier N, Cordier AG, Vauloup-Fellous C, Adle-Biassette H, Martinovic J, et al. Detailed in utero ultrasound description of 30 cases of congenital cytomegalovirus infection. Prenat Diagn. 2014 Jun;34(6):518-24. [PubMed] [Crossref].

18. Liesnard C, Donner C, Brancart F, Gosselin F, Delforge ML, Rodesch F. Prenatal diagnosis of congenital cytomegalovirus infection: prospective study of 237 pregnancies at risk. Obstet Gynecol. 2000 Jun;95(6 Pt 1):881-8. [PubMed] [Crossref].

19. Gouarin S, Gault E, Vabret A, Cointe D, Rozenberg F, Grangeot-Keros L, et al. Real-time PCR quantification of human cytomegalovirus DNA in amniotic fluid samples from mothers with primary infection. J Clin Microbiol. 2002 May;40(5):1767-72. [PubMed] [Crossref].

20. De Paschale M, Agrappi C, Manco MT, Clerici P. Positive predictive value of anti-HCMV IgM as an index of primary infection. J Virol Methods. 2010 Sep;168(1-2):121-5. [PubMed] [Crossref].

Please cite this article as: Stoykova Z. Serological CMV screening in women of reproductive age and in pregnant women. J of IMAB. 2019 Oct-Dec;25(4):2755-2758. DOI: https://doi.org/10.5272/jimab.2019254.2755

Received: 19/03/2019; Published online: 04/11/2019

\author{
Address for correspondence: \\ Zhivka Stoykova, MD, PhD \\ Laboratory of Virology, University Hospital St. Marina, Varna \\ 1, Hristo Smirnenski Blvd, 9010, Varna, Bulgaria \\ e-mail: jivita77@abv.bg; jivka.demireva@mu-varna.bg
}

